\title{
Back to Basics: Estimating Protein Requirements for Adult Hospital Patients. A Systematic Review of Randomised Controlled Trials
}

\author{
Suzie Ferrie ${ }^{1,2^{*}}$, Samantha Rand ${ }^{2}$, Sharon Palmer ${ }^{3}$ \\ ${ }^{1}$ Royal Prince Alfred Hospital, Sydney, Australia; ${ }^{2}$ University of Sydney, Sydney, Australia; ${ }^{3}$ A Passion 4 Good Nutrition, Camp- \\ belltown, Australia. \\ Email: * suzie.ferrie@sswahs.nsw.gov.au
}

Received December $4^{\text {th }}, 2012$; revised January $4^{\text {th }}, 2013$; accepted January $11^{\text {th }}, 2013$

\begin{abstract}
Aim: To review the supporting evidence for protein requirements in hospitalised adults, and compare the findings with commonly-used guidelines and resources. Methods: a systematic review was conducted based on a computerised bibliographic search of MEDLINE, EMBASE and CINAHL from 1950 to October 2011, as well as a citation review of relevant articles and guidelines. Studies were included if they were randomised clinical trials in hospitalised or chronically ill adults, comparing two or more different levels of protein intake. Information about study quality, setting, and findings was extracted using standardised protocols. Due to the heterogeneity of study characteristics, no meta-analysis was undertaken. Results: 116 papers were obtained in the search and 33 of these met all inclusion criteria. Five studies could not be obtained. The remainder reported outcome measures such as nitrogen balance, anthropometric measurements (including body weight, BMI, and mid-arm circumference), blood electrolyte levels and serum urea, which provide support for recommended protein intakes in various clinical conditions. The results were summarized and compared with current recommendations. Conclusion: high-level evidence to support current recommendations is lacking. The studies reviewed generally agreed with current guidelines and resources.
\end{abstract}

Keywords: Nutrition Assessment; Protein Metabolism; Dietary Protein; Nutrition Support

\section{Introduction}

Dietary protein is required by adults to supply the amino acids needed for the synthesis and maintenance of body proteins. In addition to making up the structures of muscles and organs, proteins fulfil a wide range of functions in the body including transportation, storage, detoxification, signalling, maintenance of $\mathrm{pH}$ and fluid homoeostasis, hormone and enzyme activities, the body's immune function, and as an energy source [1].

Proteins are synthesized and catabolised in a continuous turnover process. In health, equilibrium in the nitrogen balance, or the total nitrogen input minus the total nitrogen loss, is achieved by a normal dietary protein intake which replaces protein losses; any protein in excess of these needs is metabolized for energy [1]. Influences on protein turnover include exercise, diet and hormone effects. For example, thyroid hormone increases protein turnover rate; growth hormone stimulates anabolism; glucocorticoids decrease protein synthesis and stimulate catabolism [2] while anabolic steroids such as

*Corresponding author. testosterone have the opposite effect, increasing protein synthesis and decreasing catabolism [3]. Insulin appears to inhibit muscle breakdown [4].

In healthy adults, a wide range of dietary protein intake is consistent with health as long as energy intake is sufficient. When protein intake is low, catabolism is inhibited if adequate carbohydrate or fat is present to use as an energy source as an alternative to breaking down protein [1]. Increasing energy intake, while keeping protein intake constant, improves nitrogen balance [1]. Conversely if there is inadequate energy contribution from another macronutrient source, even at very high protein intakes it is possible to starve to death [5] and a diet consisting solely of protein does not produce a better nitrogen balance than a protein-free low-energy diet (below $2500 \mathrm{~kJ} /$ day) [6]. Partly this is because the breakdown of protein for conversion to fat and glucose is not very efficient and the diet-induced thermogenesis is so much higher for pure protein diets (around 30\% of the energy ingested) when compared with fat $(6 \%-14 \%)$ and carbohydrate (6\%) [7-9]. This means that a larger total energy intake is required to maintain constant body weight 
when the diet is extremely high in protein.

Estimating requirements for protein is much more difficult than estimating requirements for energy, because the methodology is difficult to standardize and many different poorly-defined factors can influence the result, including wide variation in metabolic demand, body protein losses, growth patterns, activity, environment, diet (including micronutrients) and protein quality and digestibility [1]. As well as the total amount of protein required, the need for a balance of individual amino acids (the "biological value" of the protein) becomes important when diets are low in protein and energy, or where protein requirements are increased. Biological value of protein, however, is not a fixed or generalisable concept since metabolic demand can slowly adapt to protein intake, effectively altering the "value" obtained by different individuals [10].

Various countries' recommendations for protein intake in healthy people $[1,11,12]$ are based on nitrogen balance studies in young healthy people receiving protein of high biological value and digestibility. For adults older than 70 years, some countries' recommendations are around $25 \%$ higher but this is controversial [1].

Recommendations for protein intake may be expressed as whole-number daily amounts of protein or in terms of grams per kilogram bodyweight, either grams of total protein or grams of nitrogen. In overweight and underweight people an adjusted weight value could be used, as with energy estimations (and for similar reasons) [13]. The nitrogen content can be estimated by dividing the protein amount by 6.25 (this assumes that protein has an average nitrogen content of 16 percent but this percentage may vary significantly depending on the amino acid profile of the diet [14]).

A recommended upper level is usually set for protein intake due to concerns that excessive protein might have detrimental effects on bone density (by increasing bone mineral loss due to increased renal acid load) and on kidney function (by increasing the amount of work the kidneys need to do in excreting waste) [11]. There is little strong evidence to support these concerns about the longterm effects of high protein intakes, however, and epidemiological studies using oral diets are confounded by the possible health risks associated with increased intakes of particular protein food sources (such as red or processed meats, or foods high in salt and saturated fat). For example, an analysis of over 20,000 healthy Greek participants in the EPIC study (European Prospective Investigation into Cancer and nutrition) [15] with mean five-year follow-up found that mortality correlated with increase in dietary protein intake, with a $13 \%$ increase in mortality risk per decile of protein intake. The correlation was stronger if carbohydrate intake decreased at the same time (controlled for total energy intake and other con- founders); the mean protein intake in this study was $76 \mathrm{~g}$ (SD $24 \mathrm{~g}$ ) per day. It is possible that this pattern of increased protein and decreased carbohydrate represents a shift from the protective traditional Greek diet and therefore does not mean that the increased mortality was a direct effect of protein intake per se. The Swedish Women's Lifestyle and Health study of over 40,000 women [16] found a similar pattern of increased mortality risk (especially cardiovascular mortality) with increased protein and/or decreased carbohydrate intake, which the researchers attributed to the popularity of unhealthy low-carbohydrate/high-protein weight loss diets. Other large epidemiological studies have found no such relationship between protein intake and health outcome $[17,18]$.

Protein requirements are altered in illness, by metabolic changes as well as by reduced intake and activity. Muscle activity inhibits protein breakdown and stimulates synthesis [19]. Atrophy of muscle, due to disuse, is a result mainly of increased breakdown but also a decrease in synthesis [20]; keeping the muscle passively stretched appears to inhibit this atrophy by reducing breakdown and increasing synthesis [21]. In trauma and infection, cytokines produced as part of the inflammatory response cause an increase in both protein synthesis and catabolism, but the increase in catabolism outweighs the increase in synthesis leading to net muscle breakdown $[22,23]$. (A loss of 1 kilogram of lean body protein tissue is equivalent to a loss of about 30 grams of nitrogen [24].) In cancer cachexia and in malnutrition, synthesis is decreased as well [25]. The ideal protein intake during illness therefore varies according to the disease state and should be evaluated on the basis of the patient's outcome, rather than simple measurement of nitrogen balance or extent of catabolism. While optimal nutrition may reduce the extent of body protein losses, even very aggressive nutrition support cannot completely suppress inflammation-related catabolism [26].

A recent survey [27] of hospital dietitians in Australia and New Zealand found that most were using established guidelines or pocket book manuals to work out protein requirements for their patients. Few reported that they had ever referred to original research on this topic. A closer look at the recommendations in these guidelines [28-33] and manuals [34,35] reveals that some are completely unreferenced and others are "expert opinion" level of evidence. Many of the references are old, and some are studies of specific amino acids rather than total protein requirements; some of the guidelines cite only other guidelines or textbooks to support their recommendations. It appears that no recent systematic review has been conducted. The aim of this project was to develop a summary of the evidence base on protein requirements in illness, using a systematic review method- 
ology focusing on randomised controlled trials to obtain the highest levels of evidence to support protein recommendations in adults during illness.

\section{Methods}

\subsection{Search Strategy}

This systematic review was conducted using the PRISMA Statement for guidance [36]. A search was conducted using four online databases (MEDLINE, EMBASE, CINAHL and Web of Science) from the earliest date available in each, using the search terms listed in Figure 1. A citation review of relevant practice guidelines and of other key articles was also conducted. No exclusion criteria were used for the initial search: all studies potentially of interest (based on title and abstract) were obtained in full-text form and then examined by two independent reviewers against the following inclusion criteria: study is a randomized controlled trial design, study population consists of hospitalized or ill adults, and study compares at least two different levels of dietary protein intake (see Figure 1). Studies other than randomized controlled trials were excluded to minimize the effects of the many confounders present in other study designs and to optimize the level of evidence being considered.

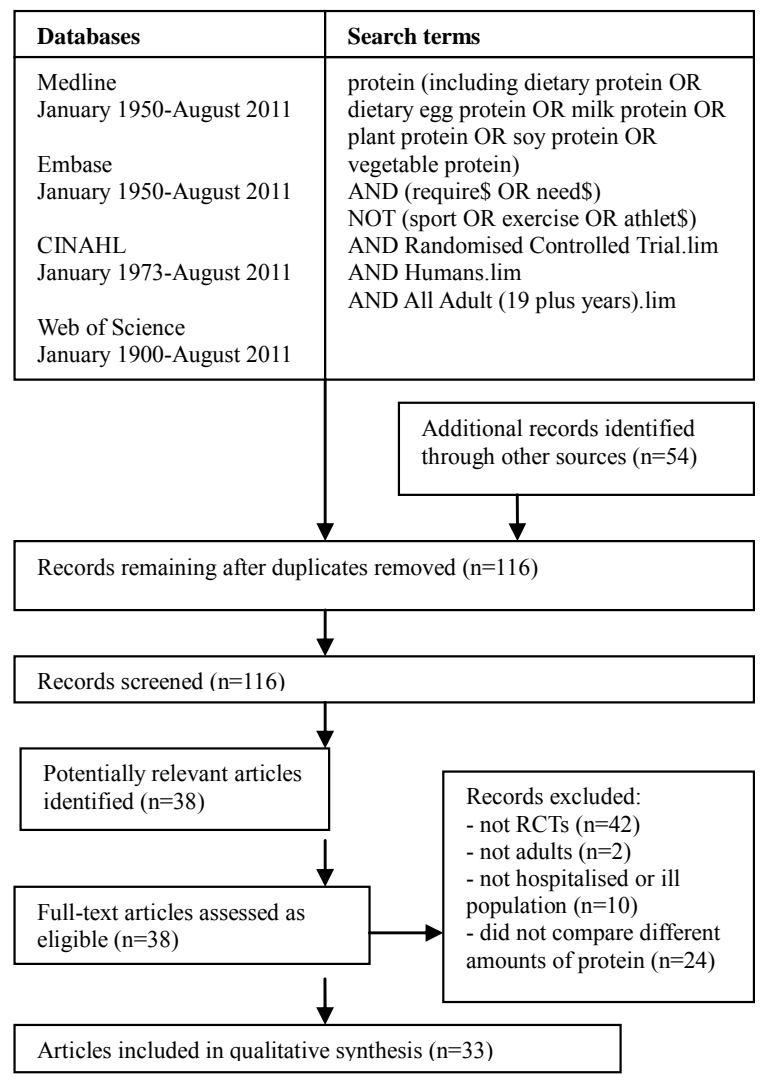

Figure 1. Flow diagram for search strategy.

\subsection{Quality Scoring}

The quality and risk of bias of all included studies were rated by two independent reviewers, against the American Dietetic Association's research quality criteria checklist [37]. Any discrepancies in rating were resolved by discussion, and final assessments were reported as "exceptional quality" (++), "high quality" (+), "neutral" $(\mathrm{O})$, or "poor" $(-)$ in accordance with the checklist scoring.

\subsection{Statistical Analysis}

No meta-analyses were performed. Chi square tests were used to assess whether lower-quality and higher-quality studies differed with respect to statistical power and choice of study outcome variables. A p-value of $<0.05$ was considered to be significant.

\section{Results}

Using the search outlined in Figure 1, 116 studies remained once duplicates were removed. Of this total, 38 met all inclusion criteria, that is, they were randomized studies of hospitalized or ill adults comparing two or more levels of protein. Five of the studies could not be obtained. The remaining 33 studies are listed in Table 1. They covered diagnostic groups including trauma/burns ( $\mathrm{n}=7$ studies), critical illness and sepsis $(\mathrm{n}=10)$, renal $(\mathrm{n}=14)$, HIV/AIDS $(\mathrm{n}=2)$ and liver disease $(\mathrm{n}=2)$.

After rating of study quality, 23 studies were rated as high or exceptional quality, and ten were rated as neutral or poor quality studies. A summary table was prepared that included the findings from only high or exceptional quality studies (Table 2) as well as currently-used guidelines. Due to study heterogeneity, no meta-analyses were possible.

The most commonly-used outcome used in the included studies was nitrogen balance (including nitrogen input and excretion rates) which was measured in twothirds of the studies. Other outcomes reported included anthropometric measurements such as body weight, Body Mass Index, waist-to-hip ratio and mid-arm circumference; laboratory tests such as urea excretion rates and glomerular filtration rates; and more general measures like quality of life, function, and nutritional status. Higherquality studies were no more likely than lower-quality studies to use nitrogen balance as an outcome $(\mathrm{p}=0.537)$ or to use more patient-focused outcomes such as quality of life or functional status $(\mathrm{p}=0.407)$.

\section{Discussion}

This review was conducted in order to summarize current evidence on the protein requirements of hospitalized or 
A Systematic Review of Randomised Controlled Trials

Table 1. Summary of protein requirements for adult hospital patients.

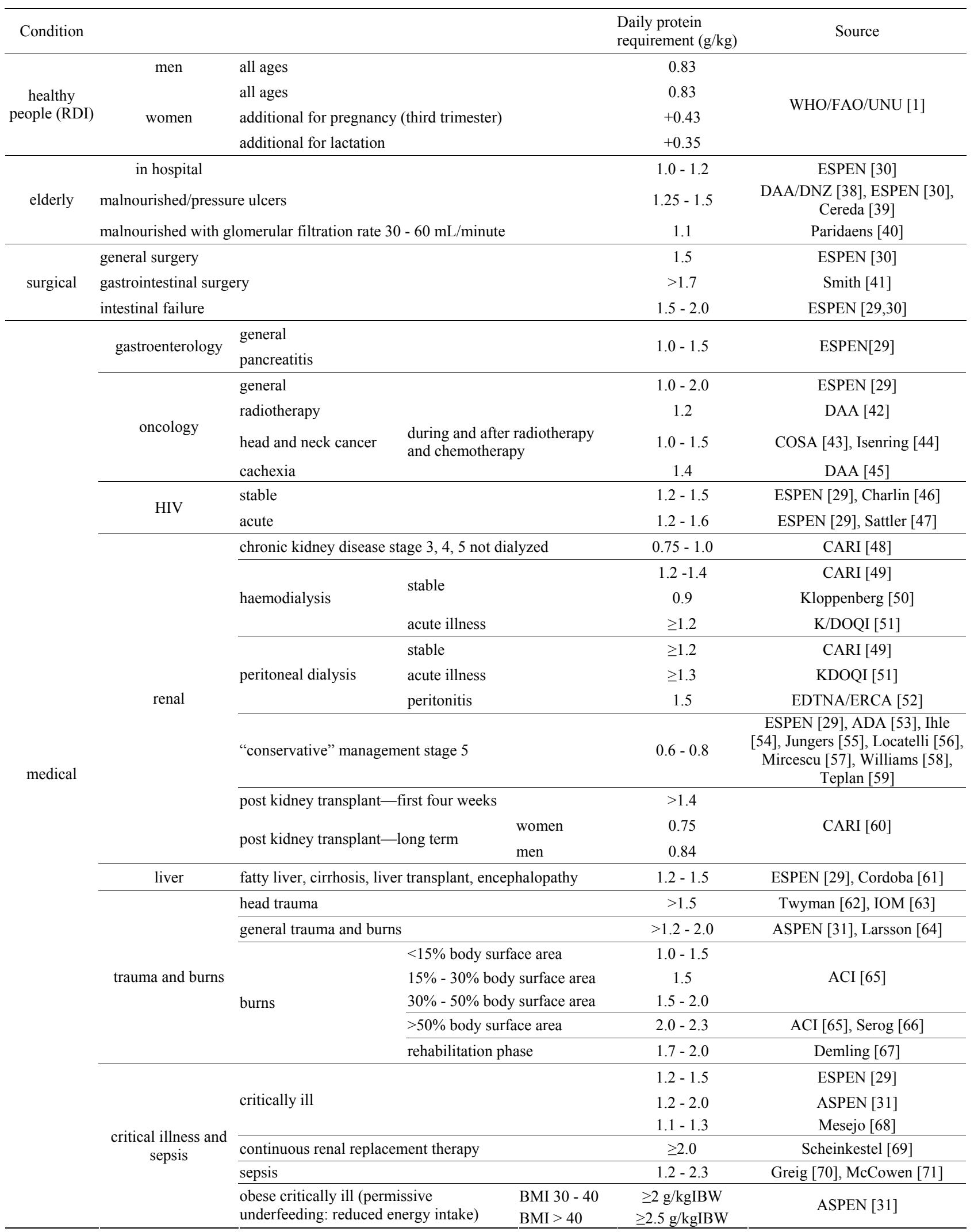

BMI: Body Mass Index; IBW: Ideal Body Weight. 
A Systematic Review of Randomised Controlled Trials

Table 2. Summary of included studies.

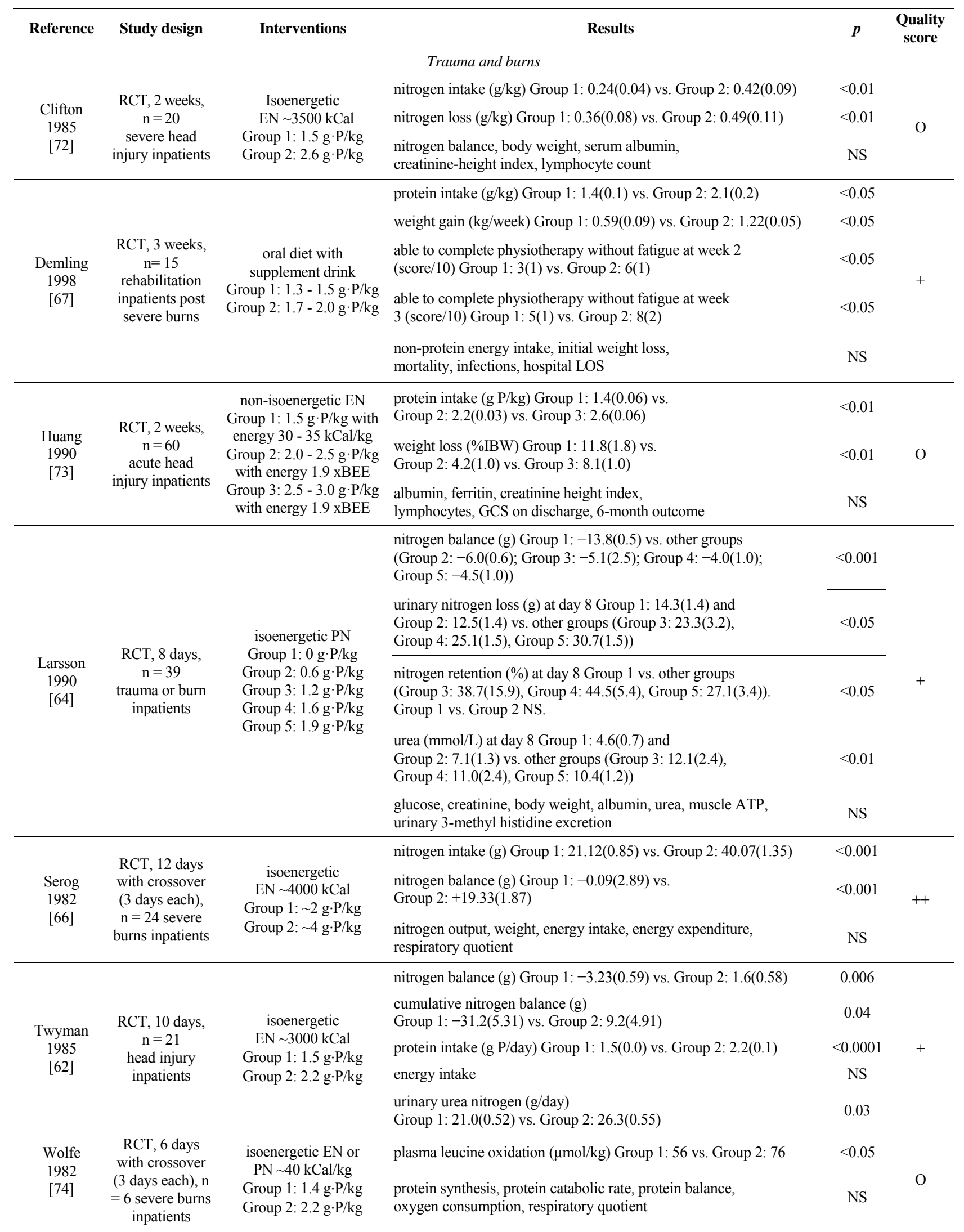




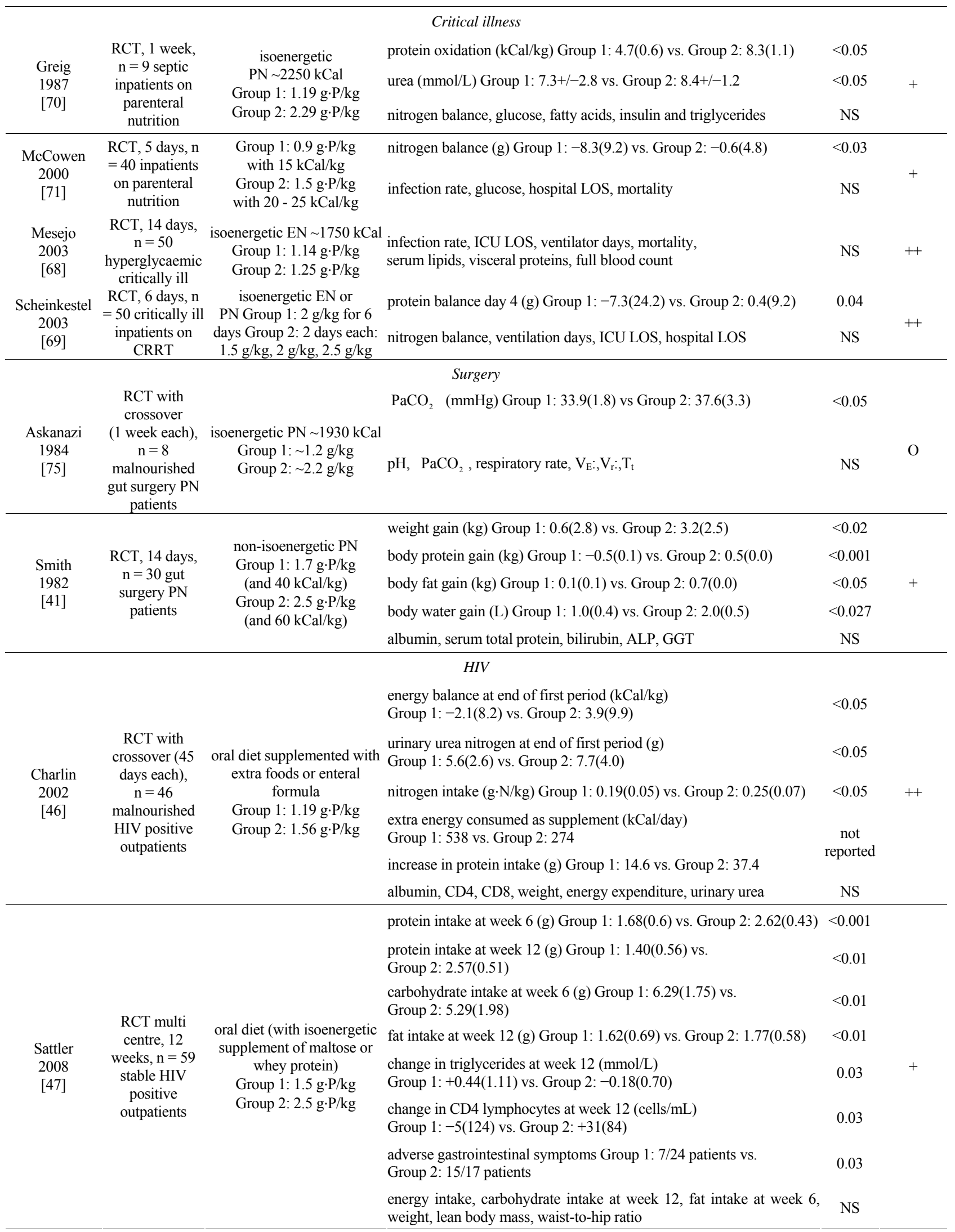




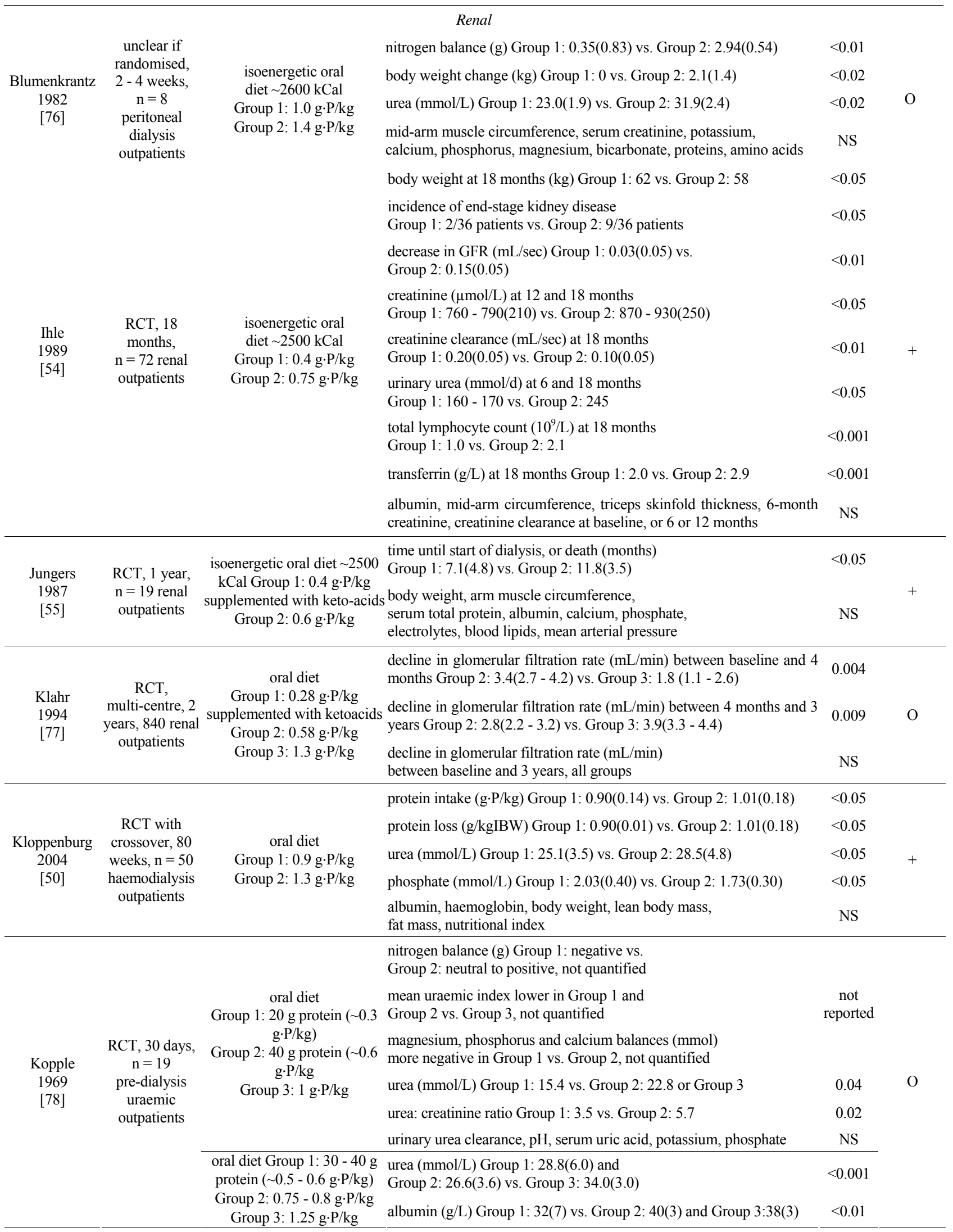




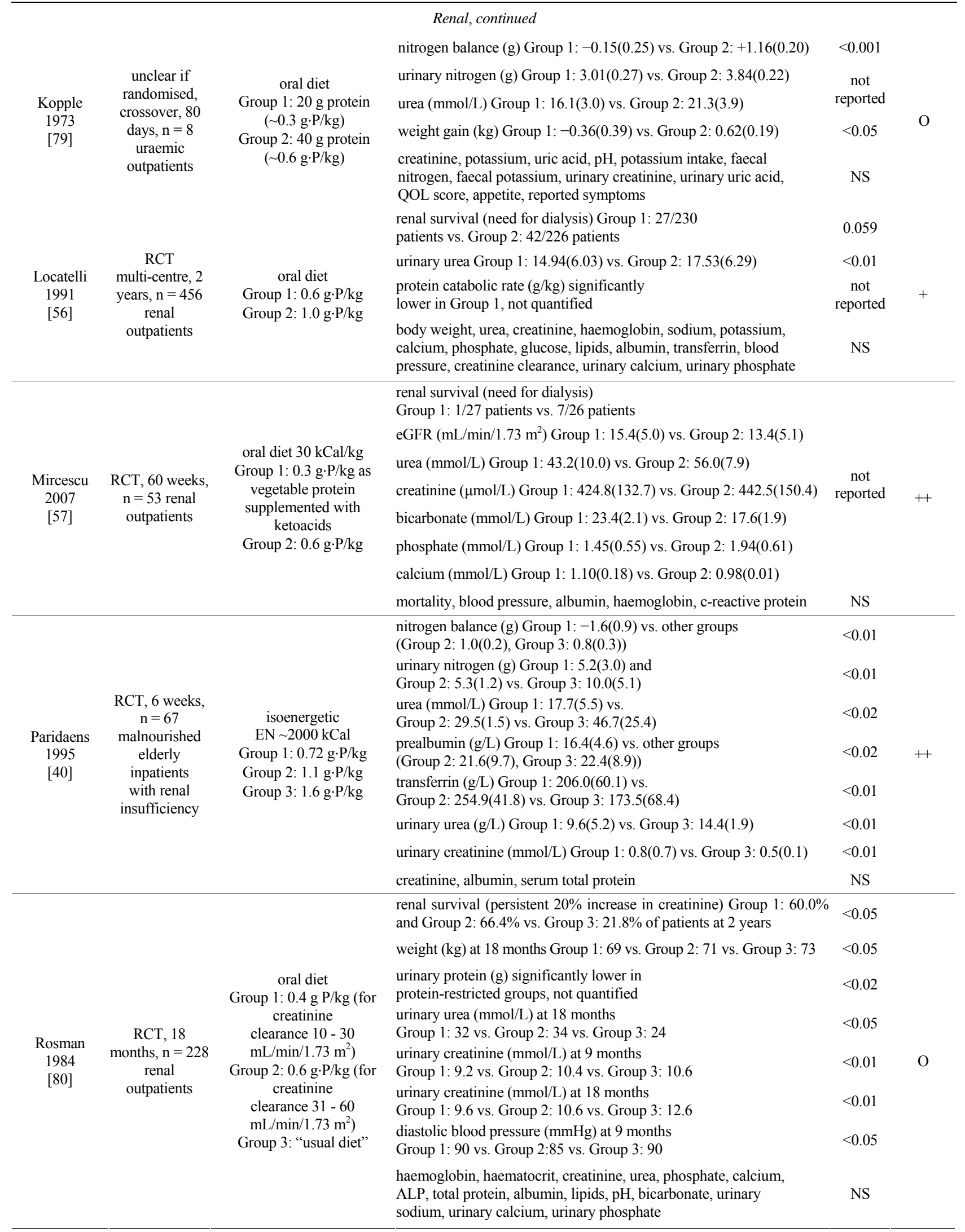




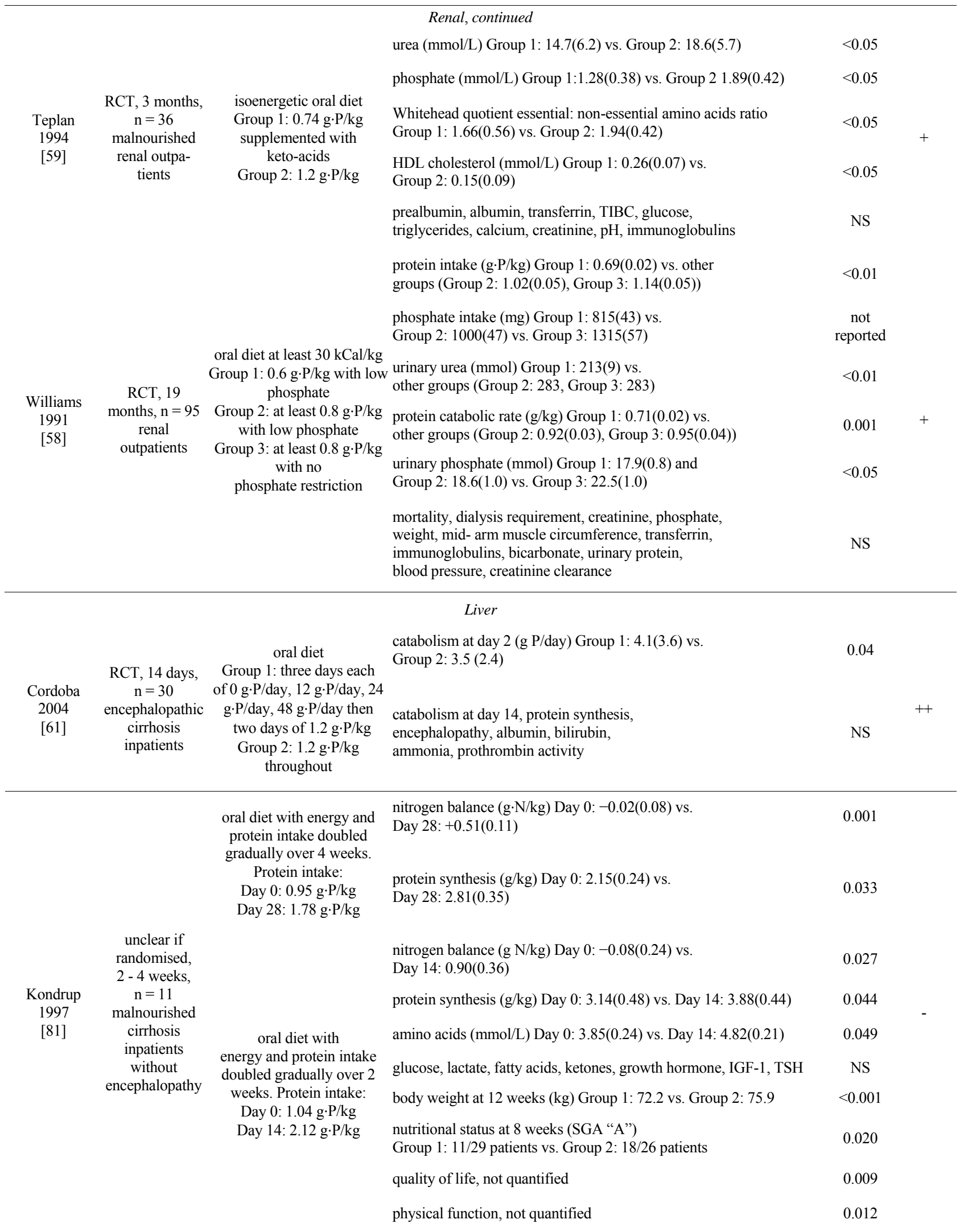




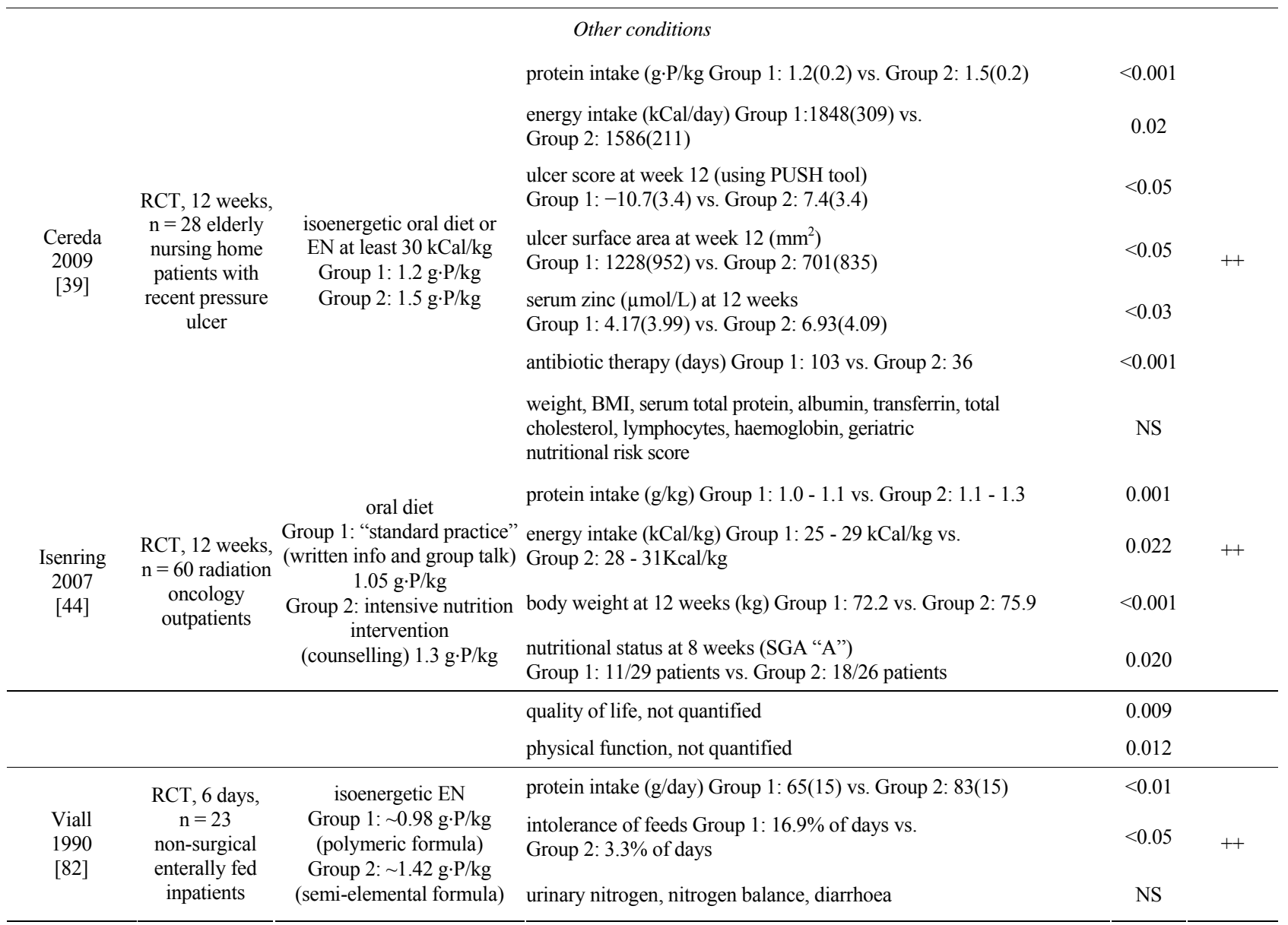

$\mathrm{P}=$ protein $\mathrm{RCT}=$ randomised controlled trial; $\mathrm{PN}=$ parenteral nutrition; $\mathrm{EN}=$ enteral nutrition; $\mathrm{BEE}=$ basal energy expenditure; $\mathrm{IBW}=\mathrm{ideal}$ body weight; GCS = glasgow coma score; LOS = length of stay; ICU = intensive care unit; NS = not significant; ALP = alkaline phosphatase; GGT = gamma glutamyl transferase; HDL = high-density lipoprotein cholesterol; BMI = body mass index; IGF-1 = insulin-like growth factor 1; TSH = thyroid-stimulating hormone; $\mathrm{SGA}=$ subjective global assessment of nutritional status; Note all values are serum levels unless otherwise stated.

chronically ill adults. A limitation of all macronutrient studies is the effect of one macronutrient on total energy intake and/or the proportions of other macronutrients. For protein, in particular, this presents difficulties because protein requirement is affected by total energy intake. The effects of altering protein intake may therefore be confounded if energy intake is also changed. However, replacing protein with either carbohydrate or fat in isoenergetic studies may not be neutral as to effect. Of the 33 studies, 10 were not isoenergetic $[39,41,44,46,64$, $71,73,75,80,81]$ and additionally a further three $[58,59,77]$ did not provide sufficient detail to ascertain this. A number of the studies also failed to assess actual intake (as distinct from prescribed intake) [54,56,57,59,61,64,74, $78,80]$. This is not only relevant for oral diets where intake is voluntary, but also in non-volitional feeding (enteral or parenteral) where intake may be interrupted for various reasons including tube problems, medication administration, surgical procedures, and poor tolerance of the nutrition. Without such an assessment it is unclear whether the studies' findings were actually the result of different protein intakes.

The value of clinical trial findings in predicting protein requirements may be compromised by the outcome measures chosen, if these are clinically meaningless or lacking in wide applicability. Accurate measures of protein synthesis and breakdown, using radiolabelled amino acids, are not in general use and were employed in only one of the studies reviewed. More commonly, nitrogen balance is used, based on urinary urea or urinary nitrogen assays along with an estimate of non-urine protein losses. It could be argued that it is more meaningful to assess protein requirements in terms of more concrete, patientfocused outcome measures such as survival and function, however, most of the studies reviewed here were too small to be powered adequately for measuring any such outcome. More than two-thirds of the studies had 50 participants or fewer (five studies had fewer than ten sub- 
jects). Only seven studies $[44,47,50,56,61,68,80]$ included any sample size calculations. Of these, the studies rated as lower-quality studies were no more likely to be under-powered than higher-quality studies $(p=0.817)$.

Recommendations for protein intake vary according to clinical condition, but for some diagnostic groups there is little high-level evidence available. This is also the main limitation of this review, namely the small number of studies and the suboptimal quality of many of these. Five studies were not possible to obtain within the limited resources of this project. Of those obtained, one-third of studies were scored neutral or poor quality. In general, older studies were the most likely to score poorly due to inadequate description of randomisation, blinding and allocation concealment in particular, with newer work reflecting the contemporary emphasis on thorough reporting and careful study design.

At present, nutritional prescriptions are quite imprecise, based on wide recommended ranges and lacking in ways to evaluate the patient's ongoing nutritional progress. Particularly in the case of protein requirements, there is a need for future research to inform these prescriptions, with adequately-powered well-controlled studies investigating a range of different intakes and assessing the results in concrete, patient-focused ways. The limited availability of high-level evidence for some of the diagnostic groups, and the significant heterogeneity within some groups (critical care in particular) indicates a need for further research in specific illnesses. However, it is reassuring to find that the studies included in this review do report protein intakes similar to those included in the guidelines and pocketbooks that dietitians are currently using to guide the nutritional care of their patients.

\section{REFERENCES}

[1] World Health Organization, Food and Agriculture Organization of the United Nations, and UN University, "Protein and Amino Acid Requirements in Human Nutrition: Report of a Joint WHO/FAO/UNU Expert Consultation," WHO Technical Report Series 935, Geneva, 2007.

[2] A. Goldberg and D. Goldspink, "The Influence of Food Deprivation and Adrenal Steroids on DNA Synthesis in Various Mammalian Tissues," American Journal of Physiology, Vol. 288, No. 1, 1975, pp. 310-317.

[3] I. Brodsky, P. Balagopal and K. Nair, "Effects of Testosterone Replacement on Muscle Mass and Muscle Protein Synthesis in Hypogonadal Men: A Clinical Research Center Study," Journal of Clinical Endocrinology and Metabolism, Vol. 81, No. 10, 1996, pp. 3469-3475. doi:10.1210/jc.81.10.3469

[4] L. S. Chow, R. C. Albright, M. L. Bigelow, G. Toffolo, C. Cobelli and K. S. Nair, "Mechanism of Insulin's Anabolic Effect on Muscle: Measurements of Muscle Protein Synthesis and Breakdown Using Aminoacyl tRNA and Other
Surrogate Measures," American Journal of PhysiologyEndocrinology and Metabolism, Vol. 291, No. 4, 2006, pp. E729-E736. doi:10.1152/ajpendo.00003.2006

[5] V. Stefansson, "Arctic Manual," Macmillan, New York, 1944.

[6] D. H. Calloway and H. Spector, "Nitrogen Balance Is Related to Caloric and Protein Intake in Active Young Men," American Journal of Clinical Nutrition, Vol. 2, No. 6, 1954, pp. 405-412.

[7] D. A. D'Alessio, E. C. Kavle, M. A. Mozzoli, et al., "Thermic Effect of Food in Lean and Obese Men," Journal of Clinical Investigation, Vol. 81, No. 6, 1988, pp. 17811789. doi:10.1172/JCI113520

[8] E. Jequier, "Thermogenesis Induced by Nutrient Administration in Man," Infusionstherapie, Vol. 11, No. 4, 1984, pp. 184-188.

[9] N. Tentolouris, S. Pavlatos, A. Kokkinos, D. Perrea, S. Pagoni and N. Katsilambros, "Diet-Induced Thermogenesis and Substrate Oxidation Are Not Different between Lean and Obese Women after Two Different Isocaloric Meals, One Rich in Protein and One Rich in Fat," Metabolism-Clinical and Experimental, Vol. 57, No. 3, 2008, pp. 313-320. doi:10.1016/j.metabol.2007.10.004

[10] D. J. Millward, “An Adaptive Metabolic Demand Model for Protein and Amino Acid Requirements," British Journal of Nutrition, Vol. 90, No. 2, 2003, pp. 249-260. doi:10.1079/BJN2003924

[11] Australian Government Department of Health and Ageing, National Health and Medical Research Council, and New Zealand Ministry of Health, "Nutrient Reference Values for Australia and New Zealand," Commonwealth of Australia, Canberra, 2006.

[12] US Food and Nutrition Board, "Dietary Reference Intakes (DRIs): Recommended Intakes for Individuals," Institute of Medicine, US National Academies, Washington DC, 2004.

[13] S. Ferrie and M. Ward, "Back to Basics: Estimating Energy Requirements for Adult Hospital Patients," Nutrition \& Dietetics, Vol. 64, No. 3, 2007, pp. 192-199.

[14] F. Mariotti, D. Tomé and P. P. Mirand, "Converting Nitrogen into Protein-beyond 6.25 and Jones' Factors," Critical Reviews in Food Science and Nutrition, Vol. 48, No. 2, 2008, pp. 177-184.

doi:10.1080/10408390701279749

[15] A. Trichopoulou, T. Psaltopoulou, P. Orfanos, C. Hsieh and D. Trichopoulos, "Low-Carbohydrate-High-Protein Diet and Long-Term Survival in a General Population Cohort," European Journal of Clinical Nutrition, Vol. 61, No. 5, 2007, pp. 575-581.

[16] P. Lagiou, S. Sandin, E. Weiderpass, et al., "Low Carbohydrate-High Protein Diet and Mortality in a Cohort of Swedish Women," Journal of Internal Medicine, Vol. 261, No. 4, 2007, pp. 366-374. doi:10.1111/j.1365-2796.2007.01774.x

[17] L. E. Kelemen, L. H. Kushi, D. R. Jacobs Jr. and J. R. Cerhan, "Associations of Dietary Protein with Disease and Mortality in a Prospective Study of Postmenopausal 
Women," American Journal of Epidemiology, Vol. 161, No. 3, 2005, pp. 239-249. doi:10.1093/aje/kwi038

[18] T. L. Halton, W. C. Willett, S. Liu, et al., "Low-Carbohydrate Diet Score and the Risk of Coronary Heart Disease in Women," New England Journal of Medicine, Vol. 355, No. 19, 2006, pp. 1991-2002. doi:10.1056/NEJMoa055317

[19] D. F. Goldspink, "The Influence of Activity on Muscle Size and Protein Turnover," Journal of Physiology, Vol. 264, No. 1, 1977, pp. 283-296.

[20] A. L. Goldberg, "Protein Turnover in Skeletal Muscle: Effects of Denervation and Cortisone on Protein Catabolism in Skeletal Muscle," Journal of Biological Chemistry, Vol. 244, No. 12, 1969, pp. 3223-3229.

[21] T. Kameyama and J. D. Etlinger, "Calcium-Dependent Regulation of Protein Synthesis and Degradation in Muscle," Nature, Vol. 279, 1979, pp. 344-346. doi: $10.1038 / 279344 \mathrm{a} 0$

[22] M. J. Rennie, "Muscle Protein Turnover and the Wasting Due to Injury and Disease," British Medical Bulletin, Vol. 41, No. 3, 1985, pp. 257-264.

[23] P. O. Hasselgren, P. Pedersen, H. C. Sax, B. W. Warner and J. E. Fischer, "Current Concepts of Protein Turnover and Amino Acid Transport in Liver and Skeletal Muscle during Sepsis," Archives of Surgery, Vol. 123, No. 8, 1988, pp. 992-999. doi:10.1001/archsurg.1988.01400320078016

[24] M. Shuran and R. Nelson, "Updated Nutritional Assessment of the Elderly," Geriatrics, Vol. 41, No. 7, 1986, pp. 48-70.

[25] M. J. Rennie, R. H. T. Edwards, P. W. Emery, D. Halliday, K. Lundholm and D. J. Millward, "Hypothesis: Depressed Protein Synthesis Is the Dominant Characteristic of Muscle Wasting and Cachexia," Clinical Physiology, Vol. 3, No. 5, 1983, pp. 387-398. doi:10.1111/i.1475-097X.1983.tb00847.x

[26] N. Ishibashi, L. D. Plank, K. Sando and G. L. Hill, "Optimal Protein Requirements during the First 2 Weeks after the Onset of Critical Illness," Critical Care Medicine, Vol. 26, No. 9, 1998, pp. 1529-1535. doi:10.1097/00003246-199809000-00020

[27] S. Ferrie and M. Allman-Farinelli, "Defining and Evaluating the Role of Dietitians in Intensive Care; State of Play," The European E-Journal of Clinical Nutrition and Metabolism, Vol. 6, No. 3, 2011, pp. e121-e125.

[28] D. Voss, "The CARI Guidelines: Caring for Australians with Renal Impairment: Protein in Pre-Dialysis Patients," 2012.

http://www.cari.org.au/CKD_nutrition_list_published/Pro tein_in_pre_dialysis.pdf

[29] European Society for Clinical Nutrition and Metabolism, "ESPEN Guidelines on Enteral Nutrition," Clinical Nutrition, Vol. 25, No. 2, 2006, pp. 180-360.

[30] European Society for Clinical Nutrition and Metabolism, "ESPEN Guidelines on Parenteral Nutrition," Clinical Nutrition, Vol. 28, No. 4, 2009, pp. 359-479.

[31] S. A. McClave, R. G. Martindale, V. W. Vanek, et al.,
"ASPEN Guidelines for the Provision and Assessment of Nutrition Support Therapy in the Adult Critically Ill Patient," Journal of Parenteral and Enteral Nutrition, Vol. 33, No. 3, 2009, pp. 277-316. doi: $10.1177 / 0148607109335234$

[32] Nutrition Education Materials Online (NEMO), "Estimating Energy and Protein Requirements for Adult Clinical Conditions," 2012.

http://www.health.qld.gov.au/nutrition

[33] National Institute for Health and Clinical Excellence, "Nutrition Support in Adults - Oral Nutrition Support, Enteral Tube Feeding and Parenteral Nutrition (Clinical Guideline 32)," Dietitians' Association of Australia and Dietitians New Zealand, Canberra, 2006.

[34] R. Snell, "Dietitians' Pocket Book," Curtin University of Technology School of Public Health, Bentley, 2006.

[35] R. Stewart, "Griffith Handbook of Clinical Nutrition \& Dietetics," 3rd Edition, Griffith University School of Public Health, Southport, 2009.

[36] A. Liberati, D. G. Altman, J. Tetzlaff, et al., "The PRISMA Statement for Reporting Systematic Reviews and MetaAnalyses of Studies That Evaluate Health Care Interventions: Explanation and Elaboration," Journal of Clinical Epidemiology, Vol. 62, No. 10, 2009, pp. e1-e34. doi:10.1016/j.jclinepi.2009.06.006

[37] American Dietetic Association, "ADA Quality Criteria Checklist: Primary Research," 2012. http://www.adaevidencelibrary.com/topic.cfm?cat=1317

[38] Trans-Tasman Dietetic Wound Care Group, "Evidence Based Practice Guidelines for the Dietetic Management of Adults with Pressure Injuries,” DAA and DNZ, 2011.

[39] E. Cereda, A. Gini, C. Pedrolli and A. Vanotti, "DiseaseSpecific versus Standard Nutritional Support for the Treatment of Pressure Ulcers in Institutionalized Older Adults: A Randomized Controlled Trial," Journal of the American Geriatrics Society, Vol. 57, No. 8, 2009, pp. 13951402. doi:10.1111/j.1532-5415.2009.02351.x

[40] K. Paridaens, A. M. de Cock, L. de Paepe and M. Vandewoude, "Optimal Amount of Protein in Tube Feeding in Hospitalized Geriatric Patients," Tijdschrift Gerontologie en Geriatrie, Vol. 26, No. 3, 1995, pp. 122-129.

[41] R. C. Smith, L. Burkinshaw and G. L. Hill, "Optimal Energy and Nitrogen Intake for Gastroenterological Patients Requiring Intravenous Nutrition," Gastroenterology, Vol. 82, No. 3, 1982, pp. 445-452.

[42] E. Isenring, "Evidence Based Practice Guidelines for the Nutritional Management of Patients Receiving Radiation Therapy," Nutrition \& Dietetics, Vol. 65, No. S1, 2008, pp. 1-20. doi:10.1111/j.1747-0080.2008.00252.x

[43] M. Findlay, J. Bauer, T. Brown, et al., "Evidence Based Practice Guidelines for the Nutritional Management of Adult Patients with Head and Neck Cancer," Clinical Oncological Society of Australia, Sydney, 2011.

[44] E. A. Isenring, J. D. Bauer and S. Capra, "Nutrition Support Using the American Dietetic Association Medical Nutrition Therapy Protocol for Radiation Oncology Patients Improves Dietary Intake Compared with Standard 
Practice," Journal of the American Dietetic Association, Vol. 107, No. 3, 2007, pp. 404-412. doi:10.1016/j.jada.2006.12.007

[45] J. D. Bauer, S. Ash, W. L. Davidson, et al., "Evidence Based Practice Guidelines for the Nutritional Management of Cancer Cachexia," Nutrition \& Dietetics, Vol. 63, No. Suppl S2, 2006, pp. S3-S32. doi:10.1111/j.1747-0080.2006.00099.x

[46] V. Charlin, F. Carrasco, C. Sepúlveda, M. Torres and J. Kehr, "Nutritional Supplementation According to Energy and Protein Requirements in Malnourished HIV-Infected Patients," Archivos Latinoamericanos de Nutrición, Vol. 52, No. 3, 2002, pp. 267-273.

[47] F. R. Sattler, N. Rajicic, K. Mulligan, et al., "Evaluation of High-Protein Supplementation in Weight-Stable HIVPositive Subjects with a History of Weight Loss: A Randomized Double-Blind Multicenter Trial," American Journal of Clinical Nutrition, Vol. 88, No. 5, 2008, pp. 13131321.

[48] D. Harris, M. Thomas, D. Johnson, K. Nicholls and A. Gillin, "The Caring for Australasians with Renal Impairment (CARI) Guidelines: Prevention of Progression of Kidney Disease," Nephrology, Vol. 11, Suppl. 1, 2006, pp. S2-S197. doi:10.1111/j.1440-1797.2006.00505.x

[49] D. Harris, M. Thomas, D. Johnson, K. Nicholls and A. Gillin, "The Caring for Australasians with Renal Impairment (CARI) Guidelines: Prevention of Progression of Kidney Disease," 2012.

http://www.cari.org.au/guidelines.php

[50] W. D. Kloppenburg, C. A. Stegeman, T. K. K. Hovinga, et al., "Effect of Prescribing a High Protein Diet and Increasing the Dose of Dialysis on Nutrition in Stable Chronic Haemodialysis Patients: A Randomized Controlled Trial," Nephrology Dialysis Transplantation, Vol. 19, No. 5, 2004, pp. 1212-1223. doi:10.1093/ndt/gfh044

[51] National Kidney Foundation Kidney Disease Outcome Quality Initiative (K/DOQI) Advisory Board, "K/DOQI Clinical Practice Guidelines for Nutrition in Chronic Renal Failure," American Journal of Kidney Diseases, Vol. 35, Suppl. 2, 2000, pp. S1-S140.

[52] European Dialysis and Transplantation Nurses Association (EDTNA)/European Renal Care Association (ERCA), "European Guidelines for the Nutritional Care of Adult Renal Patients," EDTNA/ERCA Journal, Vol. 29, No. 1, 2003, pp. s1-s23.

[53] K. L. Wiggins, "Guidelines for Nutritional Care of Renal Patients," 3rd Edition, Renal Dietitians Dietetic Practice Group, American Dietetic Association, Chicago, 2002.

[54] B. U. Ihle, G. J. Becker, J. A. Whitworth, R. A. Charlwood and P. S. Kincaid-Smith, "The Effect of Protein Restriction on the Progression of Renal Insufficiency," New England Journal of Medicine, Vol. 321, No. 26, 1989, pp. 17731777. doi:10.1056/NEJM198912283212601

[55] P. Jungers, P. Chauveau, F. Ployard, B. Lebkiri, C. Ciancioni and N. K. Man, "Comparison of Ketoacids and Low Protein Diet on Advanced Chronic Renal Failure Progression," Kidney International, Vol. 32, Suppl. 22, 1987, pp. S67-S71.
[56] F. Locatelli, D. Alberti, G. Graziani, G. Buccianti, B. Redaelli and A. Giangrande, "Prospective Randomised Multicentre Trial of Effect of Protein Restriction on Progression of Chronic Renal Insufficiency," Lancet, Vol. 337, No. 8753, 1991, pp. 1299-1304. doi:10.1016/0140-6736(91)92977-A

[57] G. Mircescu, L. Gârneață, S. H. Stancu and C. Căpuşă, "Effects of a Supplemented Hypoproteic Diet in Chronic Kidney Disease," Journal of Renal Nutrition, Vol. 17, No. 3, 2007, pp. 179-188. doi:10.1053/i.jirn.2006.12.012

[58] P. S. Williams, M. E. Stevens, G. Fass, L. Irons and J. M. Bone, "Failure of Dietary Protein and Phosphate Restriction to Retard the Rate of Progression of Chronic Renal Failure: A Prospective Randomized Controlled Trial," Quarterly Journal of Medicine, Vol. 81, No. 294, 1991, pp. 837 855.

[59] V. Teplan, O. Schück, O. Mengerová and J. Růžičková, "Individually Supplemented Low-Protein Diet in Patients with Chronic Kidney Failure," Vnitrní Lékarství, Vol. 40, No. 10, 1994, pp. 623-627.

[60] S. Chadban, M. Chan, K. Fry, et al., "The Caring for Australasians with Renal Impairment (CARI) Guidelines: Protein Requirement in Adult Kidney Transplant Recipients," Nephrology, Vol. 15, Suppl. 1, 2010, pp. S68-S71. doi:10.1111/j.1440-1797.2010.01238.x

[61] J. Córdoba, J. López-Hellín, M. Planas, et al., "Normal Protein Diet for Episodic Hepatic Encephalopathy: Results of a Randomized Study," Journal of Hepatology, Vol. 41, No. 1, 2004, pp. 38-43. doi:10.1016/i.jhep.2004.03.023

[62] D. Twyman, A. B. Young, L. Ott, J. A. Norton and B. A. Bivins, "High Protein Enteral Feedings: A Means of Achieving Positive Nitrogen Balance in Head Injured Patients," Journal of Parenteral and Enteral Nutrition, Vol. 9, No. 6, 1985, pp. 679-684. doi: $10.1177 / 0148607185009006679$

[63] Institute of Medicine (IOM), "Nutrition and Traumatic Brain Injury: Improving Acute and Subacute Health Outcomes in Military Personnel," National Academies Press, Washington DC, 2011.

[64] J. Larsson, C. Lennmarken, J. Mårtensson, S. Sandstedt and E. Vinnars, "Nitrogen Requirements in Severely Injured Patients," British Journal of Surgery, Vol. 77, No. 4, 1990, pp. 413-416. doi:10.1002/bjs. 1800770418

[65] K. A'Beckett, L. Baytieh, A. Carr-Thompson, et al., "NSW Statewide Burn Injury Service Clinical Practice Guidelines for Burn Patient Nutrition Management," NSW Agency for Clinical Innovation, Sydney, 2011.

[66] P. Serog, F. Baigts and M. Apfelbaum, "Energy and Nitrogen Balances in 24 Severely Burned Patients Receiving Four Isocaloric Diets of about $10 \mathrm{MJ} / \mathrm{m}^{2} /$ Day $(2392$ Kcalories/m²/Day)," Burns, Vol. 9, No. 6, 1982, pp. 422 427. doi:10.1016/0305-4179(83)90106-7

[67] R. H. Demling and L. De Santi, "Increased Protein Intake during the Recovery Phase after Severe Burns Increases Body Weight Gain and Muscle Function," Journal of Burn Care and Rehabilitation, Vol. 19, No. 2, 1998, pp. 161168. doi:10.1097/00004630-199803000-00015 
[68] A. Mesejo, J. A. Acosta, Y. C. Ortega, et al., "Comparison of a High-Protein Disease-Specific Enteral Formula with a High-Protein Enteral Formula in Hyperglycemic Critically Ill Patients," Clinical Nutrition, Vol. 22, No. 1, 2003, pp. 295-305. doi:10.1016/S0261-5614(02)00234-0

[69] C. D. Scheinkestel, L. Kar, K. Marshall, et al., "Prospective Randomized Trial to Assess Caloric and Protein Needs of Critically Ill, Anuric, Ventilated Patients Requiring Continuous Renal Replacement Therapy," Nutrition, Vol. 19, No. 6, 2003, pp. 909-916. doi:10.1016/S0899-9007(03)00175-8

[70] P. D. Greig, D. H. Elwyn, J. Askanazi and J. M. Kinney, "Parenteral Nutrition in Septic Patients: Effect of Increasing Nitrogen Intake," American Journal of Clinical Nutrition, Vol. 46, No. 6, 1987, pp. 1040-1047.

[71] K. C. McCowen, C. Friel, J. Sternberg, et al., "Hypocaloric Total Parenteral Nutrition: Effectiveness in Prevention of Hyperglycemia and Infectious Complications-A Randomized Clinical Trial," Critical Care Medicine, Vol. 28, No. 11, 2000, pp. 3606-3611. doi:10.1097/00003246-200011000-00007

[72] G. L. Clifton, C. S. Robertson and C. F. Contant, "Enteral Hyperalimentation in Head Injury," Journal of Neurosurgery, Vol. 62, No. 2, 1985, pp. 186-193. doi:10.3171/jns.1985.62.2.0186

[73] S. L. Huang and S. T. Lee, "Nutritional Care of Severe Acute Head Injury Patients: Formulas for Early Enteral Alimentation," Journal of the Formosan Medical Association, Vol. 89, No. 6, 1990, pp. 498-503.

[74] R. R. Wolfe, R. D. Goodenough, J. F. Burke and M. H. Wolfe, "Response of Protein and Urea Kinetics in Burn Patients to Different Levels of Protein Intake," Annals of Surgery, Vol. 197, No. 2, 1982, pp. 163-171. doi:10.1097/00000658-198302000-00007

[75] J. Askanazi, C. Weissman, P. A. LaSala, J. Milic-Emili and J. M. Kinney, "Effect of Protein Intake on Ventilatory
Drive," Anesthesiology, Vol. 60, No. 2, 1984, pp. 106 110. doi:10.1097/00000542-198402000-00005

[76] M. J. Blumenkratz, J. D. Kopple, J. K. Moran and J. W. Coburn, "Metabolic Balance Studies and Dietary Protein Requirements in Patients Undergoing Continuous Ambulatory Peritoneal Dialysis," Kidney International, Vol. 21, 1982, pp. 849-861. doi:10.1038/ki.1982.109

[77] S. Klahr, A. S. Levey, G. J. Beck, et al., "The Effects of Dietary Protein Restriction and Blood-Pressure Control on the Progression of Chronic Renal Disease," New England Journal of Medicine, Vol. 330, 1994, pp. 877-884. doi:10.1056/NEJM199403313301301

[78] J. D. Kopple, J. H. Shinaberger, J. W. Coburn, M. K. Sorensen and M. E. Rubini, "Evaluating Modified Protein Diets for Uremia," Journal of the American Dietetic Association, Vol. 54, No. 6, 1969, pp. 481-485.

[79] J. D. Kopple and J. W. Coburn, "Metabolic Studies of Low Protein Diets in Uremia: Nitrogen and Potassium," Medicine, Vol. 52, No. 6, 1973, pp. 583-595. doi:10.1097/00005792-197311000-00004

[80] J. B. Rosman, P. M. Ter Wee, S. Meijer, T. P. M. PiersBecht, W. J. Sluiter and A. J. M. Donker, "Prospective Randomised Trial of Early Dietary Protein Restriction in Chronic Renal Failure," Lancet, Vol. 324, No. 8415, 1984, pp. 1291-1296. doi:10.1016/S0140-6736(84)90818-3

[81] J. Kondrup, K. Nielsen and A. Juul, "Effect of LongTerm Refeeding on Protein Metabolism in Patients with Cirrhosis of the Liver," British Journal of Nutrition, Vol. 77, No. 2, 1997, pp. 197-212. doi:10.1079/BJN19970024

[82] C. Viall, K. Porcelli, J. C. Teran, R. N. Varma and W. P. Steffee, "A Double-Blind Clinical Trial Comparing the Gastrointestinal Side Effects of Two Enteral Feeding Formulas," Journal of Parenteral and Enteral Nutrition, Vol. 14, No. 3, 1990, pp. 265-269. doi: $10.1177 / 0148607190014003265$ 